\title{
Doing public theology in the anthropocene towards life-creating theology
}

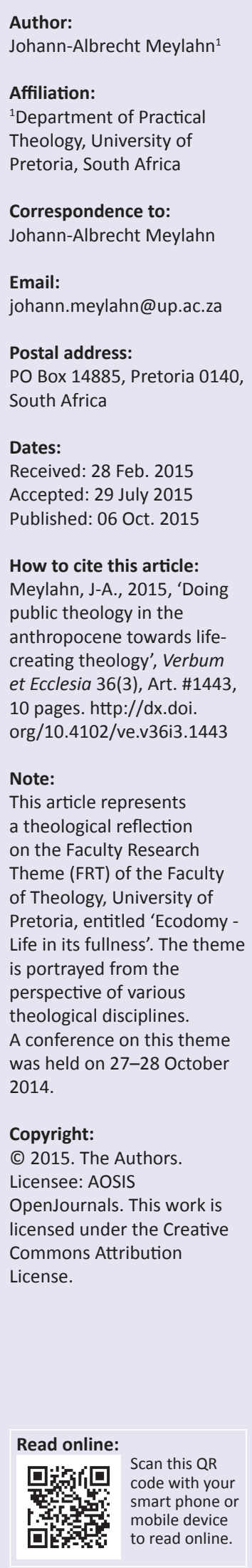

If one presumes that we are today living in the anthropocene, how does this challenge the doing of public theology? What is the calling of a public theologian in the anthropocene? To be able to answer these questions, this article shortly described the anthropocene and then sought to unpack a possible doing of theology in a particular local context, within the time of the anthropocene, creating (poiesis) a deconstructive space for possible resurrection life to emerge.

\section{The time of the anthropocene}

The time of the anthropocene 1 is the period of earth's history that we are currently living in, as it can be described as a period where the human impact on earth is equal to the great forces of nature of previous periods (Crutzen, McNeil \& Steffen 2007). In this article, a slightly different perspective or interpretation of the anthropocene is proposed. Here it is interpreted not as the impact of human culture on nature, but rather the interconnection and interdependence between nature and culture. The anthropocene is understood as an interrelatedness and interdependence between culture and nature, so much so that the distinction between the two fades. This understanding is not developed from a perspective of the physical or geological sciences, but is a perspective developed from the humanities - more specifically, from a perspective of the sociallinguistic construction of reality. Many of the ideas in this article concerning the anthropocene were inspired by ideas developed by Bruno Latour $(2005,2010,2013)$.

The anthropocene can be described as a time and space where the old dualisms between culture and nurture or culture and nature have become meaningless. A time where the time-space of human existence is a human construction, and no longer something discovered out there in nature or believed to be created by God. It is a world that humans have constructed and this construction has developed a 'life' of its own, which in turn impacts human life.

There is talk of the sixth great extinction in conjunction with the anthropocene. This extinction would, however, be the first in the history of the earth that is caused by human behaviour, or that is the result of the suicide machine - a machine that is a human construction, as Brain McLaren (2007:43ff.) describes it.

Nature was believed and presupposed to be out there, waiting to be discovered, and science was convinced that it would eventually discover all of nature's secrets once the veil of myth and religion had been lifted. It was believed that science, with its ever-increasing knowledge of nature with its 'natural' laws, would eventually be able to explain everything naturally (i.e. according to science), and that such knowledge would usher in a secular realm: a realm liberated from myths, fictions and religion. Some might argue that today's public life in the Western world is such a secular realm, as religion has been reduced to the private sphere. One might be inclined to agree that public Western life is to a large extent secular, with traditional religions being reduced to the private sphere. However, this secular public realm was not found nor discovered as believed, but it was fashioned. It was literally constructed by means of human practices, social roles, equipment and goals, and the ever-growing technical digital regime.

In this article, the anthropocene is interpreted as a humanly constructed world that has taken on a life of its own. The idea of machines becoming independent and beginning to control humans is a classic theme of numerous futuristic science fiction novels, where the roles between constructor and construction or creator and creation become fluid. These futuristic fictions are not that futuristic nor so fictitious, as most constructions have an impact on their constructors. For example, the invention of the steam engine, electricity, personal computers or the use of

1. Every living thing affects its surroundings. But humanity is now influencing every aspect of the Earth on a scale akin to the great force of nature (http://www.anthropocene.info/en/anthropocene). 
smartphones: all these inventions changed human life and, in a sense, has 'created' a very different humanity and world to the world of past generations. Humans invented and constructed machines to control and manipulate nature, and eventually these machines and constructions begin to have a controlling effect on humanity, or at least begin to codetermine human life and human living-space (world). All the wonderful inventions and developments of the last few decades have radically changed the way many people live, communicate and interact with each other.

Humans, in their striving to control and manipulate 'nature', construct systems of control with which they seek the power to control the present in the hope to be able to determine, or at least predict or secure, the future. The financial system, with its investments, insurance companies and medical aid schemes, seeks to secure the future. The financial system, linked to production and consumption, are beginning to control and determine human life, and to a large extent also non-human life. This is just a small example of how something constructed to give humanity control over the future has turned into something that is controlling not only our present, but also our future - and one could argue that it is destroying the ecological future of earth.

One can say that the cultural has become real and the real, as cultural, is responding in the form of the numerous ecological and political crises that the world is experiencing today.

The human construction, once believed to be constructed on top of or on the basis of the natural earth (nature, natural resources, water, atmosphere, etc.), is transformed. Culture is now no longer that which is constructed on the foundation of nature, but it has become nature. As Heidegger (1976) once said: ' $[W]$ e only have purely technological conditions left. It is no longer an earth on which human beings live today' (Crockett \& Robbins 2010:pos. 78 of 4148). Culture is no longer that which is constructed on the basis of nature, as an interpretation or understanding or discovery of the real, but it has become the real. Or, stated differently, the real has become culture.

The construction of a city and citizenship, and the movement into the city from the rural, was possible because it was believed that nature could be understood. And once understood, it can be used, utilised, transformed, manipulated and controlled so as to produce surplus with which to feed and house those who are living in the cities and whose lives are not directly connected to hunting, farming and gathering.

The distinction between culture-nature or knowledge (science)-nature made it possible for humans to control, manipulate and exploit nature. Modernity believed that it was only a matter of time before it would have complete control over nature. In a certain sense, modernity's dream has come true as there is no nature left beyond culture. Stated differently: there is no nature outside of culture - or, as Derrida argues, there is nothing outside of text (Derrida 1997:158).

The imminent ecological threat seems to challenge this absolute enclosure within culture, as it seems as if finite nature is clearly demarcating the boundaries of human culture. Water scarcity and finite fossil fuels can be interpreted as nature setting the limits for human development. Added to the various ecological crises, there is also the crises of civilisation itself, with the numerous political upheavals throughout the world. Are all these crises signs that human control over nature and/or 'human nature' has limits? Are these crises signs that the dominant culture is cracking up and something is forcing itself to be heard - maybe 'nature'? Is 'nature', in the form of both the environmental crisis and 'human nature' (wars, refugees, immigration, terrorism, mass demonstrations and public protests), breaking through the boundaries of the dominant culture - the dominant human political-economic-cultural construction? Are these crises alternative constructions (voices) seeking to be heard, and thereby demanding a more inclusive democracy? Are these crises a call for a democracy that would include the voice of 'nature' and other 'human needs' than those enclosed in the dominant culture?

What is becoming apparently clear is that what is needed is not only a new way of thinking, but also a new way of being in and of this world (anthropocene). This article seeks to be a small part of trying to explore this new way of thinking and being in and of this world, but from a theological perspective.

\section{The anthropocene as a grammatised context}

Bernard Stiegler $(2009,2010)$, working from within the linguistic turn in continental philosophy, argues for what Sylvain Arnoux called grammatisation (see Stiegler 2009:42). Grammatisation is the process by which (Stiegler 2009):

\begin{abstract}
... both individuals and groups individuate themselves (that is, become what they are) through expression, primarily through their utterances, but also through their gestures, perceptions and transmissions of signs as well as their actions - which are also, secondarily an output of signs and information. (p. 42)
\end{abstract}

The grammatisation process, according to Stiegler, already began in the Neolithic Age with the very first forms of notation: first the numerical systems and then later the ideograms (Stiegler 2009:43). Stiegler, following Bergson, Husserl and Barthes, describes this shift towards grammatisation as 'technics'. He (Stiegler 2010:152) traces this development from the very early forms of notation to today's highly advanced development of industrial temporal objects (photography, recordings, radio, cinema, television, YouTube). What is today often termed the digital (social media, media technologies, etc.), can be interpreted as part of the history of technics or part of the history of grammatisation - and in that sense, part of a long history of individual and group individuation through signs and communication of information. 
The movement from rural to urban in the early civilisations (see Stiegler 2009:43) began in the Neolithic Age with the earliest forms of notation. Stiegler's argument is that without the development of grammatisation, the development of the city and citizenship would not have been possible. He argues that these notations make the engramming of linguistic flux possible, and thus forms the basis of the psychic and collective individuation processes that constitutes citizenship (Stiegler 2009:43). 'The space and time of the cité, its geography and its history, or its geopolitics, are critical avant la lettre, in other words through the letter' (Stiegler 2009:43).

It is the letter (grammatisation) or the textual that made the transition to the city possible and the development of citizenship. The movement from urban towards digital, in the final stages of this process, is for Stiegler a loss of citizenship - and, in that sense, the opposite of the development of the city. Stiegler calls these new digital technologies, which form the final stages of grammatisation, 'psychotechnologies' and is highly critical of it because they enable the cultural industries to (Stiegler 2009):

... create cultural and political consumerism that destroys all forms of culture and knowledge as well as the politea as such, and not only democracy - without even mentioning the general toxicity resulting from consumerism in itself. (p. 44)

The focus of this article is on this process of grammatisation understood as writing in the broadest sense, as Derrida understands writing (see Derrida 1997). The final sections of the article returns to Stiegler's critique of the final stages of grammatisation in the digital world of YouTube, Facebook, Twitter, together with all the other forms of digital selfproduction, and this final stage of grammatisation will be brought into conversation with the anthropocene.

Derrida (1997:7) argues that writing has always already begun - not only with the advent of graphic signs, but already in speaking and audible signs.

Ricoeur (1973:91) argued that phenomena studied in sociology, or one could say that phenomena as such, can be interpreted as texts, and therefore need to be understood as part of grammatisation. Taking Derrida and Ricoeur into consideration, one could argue that one is always already in the text (in writing), and any study of phenomena in sociology or practical theology can be interpreted as texts within contexts. Yet, these texts (writing) are supplements (see Derrida 1997:141-164), and as supplements they are pharmakons (see Derrida 1981:99f.). These texts, which is all one has, are supplements and not the 'real', and can therefore be described as virtual. What practical theology studies are virtual texts within virtual contexts - or stated differently, cultural texts in cultural contexts. The material of practical theology are these texts (writing/grammatisation) rather than the real, and therefore context studies, which is the base discipline for practical theology, can be described as textual studies. If one tries to understand the contexts of practice, practices themselves, lived religion, experiences, etc. are all texts within contexts, and therefore textual phenomena that are disclosed and appropriated by a textual subject or a community of textual subjects. The subjects reading or interpreting texts are themselves texts (social-linguistic constructions).

In a sense, one can argue that humanity is caught in the web of the textual and there is no way beyond - as if one is caught in the Matrix, the movie trilogy directed by Andy and Lana Wachowski. Yet, the hope the Matrix movie offers is a false hope, as there is no Zion. There is no beyond the textual, there is no beyond the Matrix, because there is no outside text (Derrida 1997:158).

\section{The textual or anthropocene as challenge for practical theology}

Practical theology engages with texts in contexts, seeking to describe, interpret and understand them, and then transform them. The transformative task of practical theology is based on a normative aspect, in other words, some sense of what should be or of what could be happening in texts within contexts. Transformation is based on some or other idea (norm) of what is good and right, and consequently is able to critique and challenge texts within contexts. What authorises such a normative aspect? Where do these norms come from with which to judge or evaluate or criticise texts within contexts? If there is no outside the Matrix - if there is no Zion - where does the authority or inspiration for liberation or salvation (transformation) come from?

How does one critically engage with texts in context without a context-transcendent (outside text) God? Is it possible to engage critically with a context without an idea of the Good that transcends the context, or a theory that comes from outside the context with which to critique or challenge and thereby offer ways of transformation?

Alone the faith or belief in an outside (transcendent) places an infinite (ethical) demand on those who 'know the truth' to seek to liberate or save all those who are still caught in the illusion or chains of sin. In any classical theological approach, an outside, an Other, a God who is beyond, or some idea of the transcendent is needed to challenge, critique, transform and save humans (texts within contexts) enslaved in sin. Sin is interpreted as humanity's self-enclosure and therefore separation (closing itself off) from God or that which is outside (transcendent) or other to the self-enclosure.

If one would interpret this within the context of grammatisation or textually, humans are enclosed within this textual world and an outside or Other is needed to break this enclosure open. In the context of the looming environmental disaster, there are those who believe that only a return to nature can save us, where nature is understood as that which is outside of culture or the textual or grammatisation. Is nature, the ecological or political crises, outside the anthropocene (the time-space created by humanity)? There 
is no outside the anthropocene, as any interpretation, understanding or figuration of an outside would only be a human construction of that outside. There is no outside, no Zion, to save humanity in the anthropocene.

\section{Doing theology in the anthropocene without a beyond}

Can practical theology engage the context or be involved in the context without recourse to an outside, Other or transcendental infinite demand? Can practical theology be relevant to the context without receiving authority and legitimisation from beyond the context in some or other sacred text or sacred ideas (see Ganzevoort 2009), which are beyond the context or beyond the anthropocene? Do we need the wholly Other or a Holy Other (in other words, the Other who is separated in some transcendent beyond) as the necessary authority and legitimisation for critique of the contexts? Levinas argues for an understanding of the Other or the sacred in the profane: what if God is to be sought not beyond, as separated, but rather in the infinite ethical demand of the face of the neighbour (Levinas 1969:24, 1998:xv)? What difference is there between a so-called onto-theological infinite demand or a so-called immanent infinite demand? There is no difference as, together with Levinas, one can argue for an immanent transcendence or transcendence as alterity (see Stoker 2010) in the face of the other (neighbour).

What if God is not understood in transcendental terms at all, but is understood within the textual, of which the creators are not machines, like in the Matrix, but where the textual is interpreted as a consequence of language, and therefore a consequence of language-creating animals, that is, humans? What if God is not understood as a human projection, as Feuerbach argued, but in terms of human language, grammatisation or techincs - or as Žižek (2009:244) argues: as 'the way the subject's own activity is inscribed into reality'? In other words, what if God is found, not in the great beyond but in the grammatisation, the subject's own activity and how that activity (grammatisation) is inscribed into reality? This idea of God in language is echoed in Derrida, when he says that the birth of the sign is also the birth of theology. ${ }^{2}$

Agamben (2010), reflecting on Usener's (1985) book, Götternamen, argues that in polytheism:

... the name assigned to the god names this or that event of
language, this or that specific naming, this or that Sondergott.
In monotheism, by contrast, God's name names language itself.
(p. 49)

Language is the word of God, and the word of God is, in the words of Philo, an oath - it is God in so far as he reveals himself in the logos as the 'faithful one' (pistos) par excellence (Agamben 2010:49-50). God is the oath taker in the language of which humanity is only the speaker. In the Cabbala, the metaphysical origin of all language is believed to be in the

2.The sign and divinity have the same place and time of birth. The age of the sign is essentially theological. Perhaps it will never end. Its historical closure is, however, outlined' (Derrida 1997:14) name of God (Scholem 1972:59). In Monotheism language becomes divine, that is, language becomes oath - it becomes logos. Derrida explores the name of God, but with a slightly different twist, saving the name 'God' for the infinite desertification of language (see Derrida 1995:55-56).

This linguistic turn has been described as the end or closure of metaphysics. So why is there a return of religion or a religious turn in continental philosophy? What keeps the thought of God alive? The return of religion and the return of the mysterious is what Toine van den Hoogen (2013) describes as 'lived spirituality'. Lived spirituality is understood as experiences of the uncanny, experiences of contingency, experiences or frustration that life cannot be controlled and foretold, and experiences of the Geschichtlichkeit of life. These experiences bring back into daily life experiences of the Other, the mysterious, which either finds expression in religion and/or also results in a turn to magic and belief in the supernatural. This turn to magic and supernatural finds expression in various movies and novels in contemporary popular culture where magic and the supernatural are central themes.

These lived spiritual experiences are experiences of an Other and therefore cannot be conclusively integrated into coherent narratives (see Ricoeur 1984:31ff.) of the everyday same. These experiences (lived spirituality) cannot be neatly integrated into mundane everyday stories and therefore something else (extraordinary story) is necessary to explain, integrate and/ or make sense of them. It is for this reason that sacred stories (Crites 1989:69) are created. Sacred stories are created in an attempt to make sense of these inexplicable experiences. Religion, in the context of lived spirituality, would be the attempt to integrate these experiences of the Other into a meaning-world, so as to understand and interpret that which was experienced as inexplicable. Van den Hoogen (2013) argues that religion is the becoming conscious of lived spirituality. Religion in its various forms (sacred stories) can be understood as different attempts to give meaning to and make sense of the lived spiritual experiences of the unexplainable.

Within the context of post-metaphysical thought, the traditional explanations of lived spirituality with sacred stories of an all-powerful and omnipresent God have become untenable, and therefore there has been a shift towards different forms of mystical theology - for example, Richard Kearney's God who may be (2001) and Anatheism (2010), John Caputo's The weakness of God (2006) and Insistence of God (2013), and Calvin Schrag's (2002) God as otherwise than being.

These contemporary philosophers of religion and/or theologians agree that no conclusive final sacred story can be created, whilst acknowledging the possibility and mystery of an Other or Stranger, however weak and powerless the stranger may be. In these theologies or philosophies of religion, the elusive Other is emplotted into a sacred story: God who may be, anatheism, weakness of God, insistence of 
God, God as otherwise than being. A sacred story is offeredfor example, the story of hospitality where strangers and strangeness are welcomed, a story of loving the stranger and thereby receiving, through the stranger, the gift (or the grace) of the post-metaphysical and post-ontotheological 'divine'. Thus, various post-metaphysical and post-ontotheological theologies (sacred stories) are developed, but no matter how weak (Caputo 2006) these theologies might be, or how much they seek to keep the challenges of both atheism and theism in conversation (Kearney 2010), they remain sacred stories.

Post-metaphysical theologies are developed as attempts of interpreting lived spiritual experiences, which are the consequence of some or other unknowable, unexplainable and elusive Otherness that breaks in, like a thief in the night, into the texts within contexts to disrupt and disturb them, and thereby opening them. Terms that are used to express this relationship with the Other are: 'to offer welcome', 'hospitality', 'love', 'gift', 'impossible possibility', among others. There is another possibility for interpreting lived spirituality that does not necessarily end in a weak theology or anatheism. One can interpret these spiritual experiences not as the result of some or other elusive, unknowable Otherness that breaks into the textual, but as the result of 'the way the subject's own activity is inscribed into reality' (Žižek 2009:244). The experience of the Other is not necessarily anything that breaks in from outside, but is the result of a flaw or lack in grammatisation - because the textual is not real. Are these two interpretations of the unexplainable opposites? Is one hereby not again creating a dualism, where one cannot think the one without thinking the other?

The position explored here is that all we have is a text, which includes various texts (post-metaphysical theologies) concerning the Other (anatheism, weakness of God, God who may be, etc.).

All there is, is the textual, without access to either the real or a super-real Other, and yet the only way one can make sense of the textual is with some notion of the real or a metaphysical concept, as there is no escaping metaphysics (see Derrida 1997:7ff.). It is impossible to escape metaphysics as every thought-world is based on some or other transcendent or quasi-transcendent notion, which gives credibility to the various texts concerning their particular understanding of the real. This transcendent notion is based on an arbitrary decision - that is, an arbitrary choice of transcendental or quasi-transcendental notion - whereby texts are believed to relate to the real and/or Other.

What if the elusive real is interpreted in terms of a givenwithout-givenness or as a determination-in-the-last-instant (see Laruelle 2000:185-186)? The various texts seeking to understand, interpret and grasp (Begreifen) the real are a consequence of a given-without-givenness, and therefore one can speak of determination-in-the-last-instance. The real gives to thought, but without being given in thought and therefore a given-without-givenness - and yet that thought is determined-in-the-last-instance by the given-withoutgivenness. To illustrate this, the tree that stands before me is given to thought, and it comes to thought as an acacia tree. Yet, in the name 'acacia tree', the 'real' tree is not captured, thus the name clones the real tree into a textual tree via the name (text), and the name serves as a dangerous supplement, which is always also a pharmakon (see Derrida 1981). Yet, the name, 'acacia tree', is determined-in-the-last-instance by the real tree standing before me. A textual reality is cloned of the 'real' tree on the basis of some transcendental theory of knowledge (epistemology), such as realism, idealism, scientism, romanticism, social constructionism, et cetera. On the basis of that decision, reality is cloned as a vision-in-One.

This keeps one within the textual (vision-in-One), as one is caught in the Matrix without an exit, where the various transcendental decisions are not links to the other, but different theories based on arbitrary decisions - and therefore different theories (possibilities of thinking) within the visionin-One.

One cannot know the 'real' tree, but only the cloned or textual version thereof. This is what Derrida (1995:74) argues - that one cannot know the other or Other, and therefore every other is wholly Other (tout autre est tout autre).

All there is is text, or all there is is a textual clone, givenwithout-givenness yet determined-in-the-last-instance: a vision-in-One.

\section{God in the anthropocene}

Instead of seeking God beyond the anthropocene, beyond the text, the suggestion is to seek God in the text, or rather as part of the grammatisation. Derrida's (1995:55-56) suggestion is to think of God as the infinite desertification of language, and therefore not to think of God in terms of a beyond at all. Levinas (1998) also does not seek God in the beyond, but proposes to seek God in the face of the other. Levinas' suggestion of seeking God in the face of the other remains an infinite demand, as his radical ethics develops into an ethical metaphysics or ethics as first philosophy (see Levinas 1969:43, 2002). Derrida's interpretation of God, as the infinite desertification of language, has some similarities with negative theology (see Derrida 1995, 2008; Meylahn 2013b:226ff.). Although there is a similarity or proximity between différance and the God of negative theology, there is also a very important difference. Derrida does not follow the mystical turn in theology as, for example, Kearney (2010) does, as différance is not another name for God.

Following Derrida, and his close proximity and yet difference to negative theology, one can conclude that God is unknowable and therefore no conclusive statements can be made with regard to either theism or atheism. This sounds similar to Kearney's Anatheism, and yet Kearney differentiates himself from Derrida (Kearney 2010:pos. 196 of 247). Kearney argues for the mystery of the Other and develops an ethic of hospitality towards the stranger as 
a kind of post-metaphysical theology - thereby he again places an ethical demand on the individual. The knowledge of the good that Kearney offers, is to welcome strangers by offering hospitality. A weak knowledge or a theory of 'truth' or 'the good' is developed, as he seeks to develop a theology of hospitality, or a theology of love for the stranger, thereby trying to get a vulnerable grip on reality and on the elusive Other. Derrida's atheism, that can pass for theism, or Kearney's Anatheism, which keeps the question of theism and atheism in creative tension, argue the same: that no conclusive answer can be given with regard to the wholly Other who is every other, as Derrida says. What is the difference between Derrida and Kearney? Kearney still seeks to come to terms with the Other, whilst Derrida argues that it is just as true for every other, as every other is wholly other.

No conclusive statements can be made about God or about reality, and therefore all statements about theism or atheism are speculations - just as statements about reality are speculations. Derrida tries to avoid a new dualism between speculative realism and speculative mysticism concerning the Other or Stranger. The best way to avoid these different speculations is to focus on what one does have, namely texts, which one can understand as the turn to literature, rather than the turn to religion. In Kearney's Anatheism (2010) there is also a turn to literature, but towards the mystical stranger or Other in various literary texts. Kearney turns to literature by identifying themes of Otherness in three novels of Western literature. The turn to literature referred to here is the turn to text and nothing beyond text, which is a turn to the textual without anything beyond. It is a turn to what happens in texts, to turn to 'the way the subject's own activity is inscribed into reality' (Žižek 2009:244; author's italics). This could also be described as the turn to the textual, and thus a turn to the anthropocene (the time-space created by human language).

\section{Christ in the anthropocene: Christology}

The way the subject's own activity is inscribed into reality, could be stated as: the way the subject's grammatisation, and thus individuation, is inscribed. The activity of the subject is the creation of signs to supplement reality, and this supplemented or cloned reality becomes a dangerous supplement, according to Derrida, as it is always a pharmakon haunted by différance.

Laruelle (2010) argues that différance is one more transcendental decision that relates texts (inscriptions) to reality, and therefore essentially remains a philosophy of difference. Derrida does not argue that différance marks the relationship between text and reality, but différance marks, scars, disrupts and auto-deconstructs texts. It is something grammatologicalsomething that happens in texts - and yet he argues for the relationship between text and reality via his idea of the trace, which is closely linked to différance. The trace is understood as a past that was never present and a future that is always still to come (see Derrida 1982:12, 21). This past never present and future always still to come haunts the texts, and this haunting characterises the relationship between texts and its other. Laruelle argues, according to Brassier (2003:27), that this is still a non-relationship relationship. The alternative that Laruelle proposes is a radicalisation of Derrida's 'there is no outside text', namely a determination-in-the-last-instance, understood as a given-without-givenness. The best way to understand the text according to Laruelle, is as radical hyle. A radical hyle is an axiomatic utterance, determined-inthe-last-instance, a given-without-givenness, as cloned and therefore as vision-in-One. It is cloned on the basis of one or other arbitrary decision (see Brassier 2001; Meylahn 2013a). A radical hyle 'enacts matter's transcendental foreclosure to thought within thought' (Brassier 2001:10).

Derrida's haunting of the text by Otherness certainly opens the way for various forms of mysticism based on thinking, contemplating and offering hospitality to the elusive Other or strangers, and therefore it finds a lot of resonance in the various mystical turns in post-metaphysical theology. Following Laruelle, and to a certain extent Žižek, there is an alternative possibility of interpreting this relationship, without reference to the haunting of the text by a trace, namely by postulating an axiomatic heresy of a radical hyle. Laruelle's radical hyle has similarities to Derrida's dangerous supplement, understood as pharmakon, yet without trying to determine the relationship between sign and reference or between writing and reality. Derrida's interpretation of writing as dangerous supplement is based on a decision - to think of the supplement in terms of différance - and therefore reality is cloned on the basis of that decision. Laruelle's non-philosophy is closer to science as it receives the givenwithout-givenness, which is determined-in-the-last-instance, without trying to develop a philosophy or theory of the relationship based on some or other decision.

To understand the idea of the radical hyle or the givenwithout-givenness yet determined-in-the-last-instance, one can turn to one of the earliest Christian hymns: Carmen Christi, Philippians 2:5-11. The incarnation, the becoming flesh, or being inscribed into human activity (or human history or human culture) as human text, did not seek equality with God. This inscription into human activity does not seek equality with the Other. Therefore it does not seek to be the Other, but has emptied itself of all divine (Other) content. It is a given-without-givenness and yet it is believed to be the Son of God (axiomatic heresy), as it is believed to be determinedin-the-last-instance by the Other. There is no philosophy of difference that relates it to the Other as it is empty of all divine content. Christ enters the text as a radical hyle. His entrance into the textual does not connect the text to the real, but saves the textual from the infinite demand to be real and allows the text to embrace its textness, or its nakedness (see Meylahn 2010:8). The texts (writing) can embrace that they are flawed, and that communication is never perfect, but always incomplete because of a linguistic inability and impossibility, as Lacan would say (see Verhaeghe 1995). Lacan was too conclusive in his theory, specifically when he argued that 
the letter always arrives at its destination (Lacan 1972:53-55). Derrida argued that it perhaps arrives or does not arrive at its destination (Derrida 1975:44) as it is maybe haunted by the trace of the other. Laruelle (2011:254) would probably only partly agree with Derrida and argue that it is not haunted, but determined-in-the-last-instance and radically or unifacially turned towards the future, and thus the naked subjects, who have embraced their symptom, are stranger subjects not citizens, but aliens in the land (1 Pt 2:11). The stranger subject is different from Lacan's analyst, in the discourse of the analyst, who is not knowing and yet remains an expert because she or he has a very clear theory (see Meylahn 2010:6). The stranger subject's not knowing (without a clear decision) is closer to Saint Paul's not knowing, who knows nothing but Christ and him crucified. Therefore, it might be better to rather speak of a Christology where the logos has been crossed out or crucified, as it cannot be developed into a theory to be understood like Lacan's discourse of the analyst. If it was a theory that can be understood, then it would lead to work-righteousness. It is not a theory or philosophy of difference, it is not theism, or atheism, or panentheism or anatheism, but if anything it is Christ and him crucified alone: sola Christus. The stranger subjects are also closer to the faithful than Kearney's host welcoming strangers (Kearney 2010). Christ's incarnational association with the ones who are not, so as to bring to naught what is (1 Cor 1:27), cannot necessarily be understood as offering welcome to strangers, and thereby developed into a kind of mystical ethic of hospitality as Kearney (2010) does. It could be argued that Christ's association with those who are not is closer to an openness to embrace the flaws (exclusions) of language than offering hospitality to that which is beyond language. As language, the textual is but a host receiving the givenwithout-givenness and, by virtue of some or other decision, it clones the given-without-givenness or the determination-inthe-last-instance into a vision of the real as a unilateral duality. Language domesticates the given (guest) via decision to fit into the vision-in-One, and it cannot do otherwise. Language welcomes the trace (ghost) of the other and materialises it. In the moment of materialisation, something is always lost (pharmakon) or excluded - something is marginalised. Jesus' incarnation and ministry can be interpreted as focusing on these exclusions and marginalisations - on those who are lost. He focused on those who were excluded by the law (norm) and by the power discourses in the process of materialisation of the other (real). Said differently, Jesus associated with those who are excluded by the process of cloning based on some or other decision. He focused on those marginalised by the dominant grammatisations, those who were not individuated into being acceptable citizens of either the Roman Empire or the chosen people of God (Israel). Through his association with those marginalised by the dominant discourses, Christ challenged the ruling power discourses he challenged the law, thereby challenging the decision and therefore language's power of discretions. He challenged the particular grammatisations and therefore individuations forming citizens (Roman or Israel), and therefore challenged the peace of the city as such. He challenged the Pax Romana, just as he also challenged the Pharisees' and Sadducees' world of being God's chosen nation. His challenge opened what is to what is not: an alternative and yet impossible city (or kingdom), a city (or kingdom) that is always still to come, where there are no discretions into Jew and Greek, man or woman, freeman or slave (G1 3:28). By opting for the excluded - those who are not - to shame those who are, he transformed the city of citizens into a city of stranger subjects, unifacially turned towards the city that is always still to come in the time that remains.

Therefore, the public theologian challenges the death drive of the anthropocene - not with the infinite demand of a transcendent reality or Deity, but with association with those in the cracks of the anthropocene: the voiceless, those who are not yet part of the democratic conversation.

Because he challenged the city through his association with those who are not, to put to shame those that are, he was crucified by the powers that be, namely the guardians of the city - the guardians of the dominant grammatisations. His death on the cross is its utter forsakenness, as he is forsaken by God (Mt 27:46). Christ's utter forsakenness on the cross is also a forsakenness from any justification by any transcendent (Other). Therefore it is a forsakenness from any way, method, theory, or ethic or ethos or decision. The cross is not justifiable and therefore Christolegy, where the logos has been crossed out, crucified.

The resurrection after the third day is the life that is possible after the crucifixion of the laws of individuation (the laws of grammatisation) - a new impossible city to come where there is neither Jew nor Greek, freeman nor slave, man nor woman.

The city to come is not the answer to all our problems. It is not Derrida's democracy and justice to come, but that which questions all that is (see Karl Barth 2003:45-46). It is a city of stranger subjects, a city of Christians - those who are not so as to bring to naught those who are: a foolishness to the Greeks and a stumbling block to the Jews (1 Cor 1:23).

Stiegler argues that with the digital turn, as part of the final stages of grammatisation, there is also the destruction of the city and of democracy. What is the difference between the digital destruction of the city and Christology's deconstruction of the city?

\section{Christology as public theology in the anthropocene and the liberation of religious identities towards life}

How is this digital turn different from Christolegy? Both embrace the virtual or the textual. The difference is that in the digital, the textual is embraced uncritically and thus plays into the hands of the dominant discourses, such as the capitalist discourse, transforming the anthropocene into a death or suicide machine. Christology offers a critique of the dominant discourses, not by returning to some or other 
transcendent, but from within the textual itself by associating with that which the various dominant grammatisations exclude.

In the digital world, the subjects create (produce) themselves via YouTube, Facebook and the many other forms of social media. The languages or cultural images are no longer controlled by media corporations or the scribes of old (see Stiegler 2009:50), but everyone for him- or herself, and thus there is a proletarization, where the only guiding principle is consumerism. Knowledge is delegated to the machine and the machine takes over control (Stiegler 2009):

This delegation of knowledge to the machine is what makes a process of proletarization of consumers possible - the discretization is here so discreet that it is transferred to the machine entirely and escapes the receiver completely. This is why analog media permits a perfect realization of the opposition between producer and consumer - which is the reign of the scribes of the audiovisual, typical for the 20th century. (p. 50)

Self-production seems like the pinnacle of individuation and yet it is nothing but a hysterical attempt to conform to the demands of the digital big Other. What counts is not the content of the self-production, but the number of likes and shares. Facebook can be interpreted as a master discourse (Meylahn 2010:3) where the 'I' can control the other's knowledge of 'me'. Although the master discourse is driven by the desire to control the knowledge others have of me, there is the constant awareness of the number of responses, in the form of likes and shares, that one gets to the various posts on social media. Thus, there is a desire to please the anonymous digital big Other by trying to get as many friends, likes and shares as possible. Therefore,

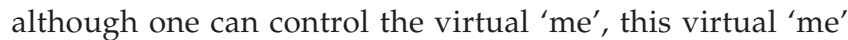
is hysterical as it seeks continuous recognition by the big digital Other. Žižek refers to this as 'the explosion of the hysterical capitalist subjectivity that reproduces itself through permanent self-revolutionizing, through the integration of the excess into the "normal" functioning of the social link' (Žižek 2006). The 'excess' is the surplus production that is continually reinvested into the market to sustain or feed the capitalist discourse (see also Meylahn 2010:4). Although the digital seems to provide numerous possibilities for individuating, in the process the individual is not individuated, but transformed into an agent of the market, and thus estranged and lost in a master discourse that is in truth a hidden discourse of the hysteric.

It is the exact opposite of Christology and the creation of stranger subjects - although the subjects or citizens of the digital city are estranged, they are not stranger subjects. They are estranged from others and from themselves as they become agents of the market, fooled into believing they are free subjects because they have the choice of various consumer products. They are fooled into believing they are free because they can reproduce themselves through social media and have the 'freedom' to choose which social media to use.
Language or grammatisation has always been textual, but the digital turn in the textual has opened new possibilities. However, through these possibilities there is also the possibility of making everyone consumers and the market taking on autonomous proportions as the sole producer, and therefore the suicide machine of the anthropocene.

The digital reveals a truth about the textual as it is an embracing of the textual, but it too easily plays into the hands of the dominant discourses, such as the capitalist discourse.

What Stiegler seems to have a problem with is the frivolity of language in the digital and its instrumentalisation within the capitalist discourse. This idea links up with Agamben's (2010:69ff.) idea of the blasphemy of much of contemporary language. What they both seek is a rediscovery of the religious (religare) or sacramental function of language that has the ability to bind citizens to a city (politea). Their critique of the capitalist discourse is certainly powerful. However, I do not agree with their method. The digital is not only blasphemous, in Agamben's sense, as it has been effectively used to bind people together in various powerful movements - the spring uprisings and the occupy movements. In these movements, the digital was used to challenge the dominant power discourses and it had a binding force: binding (religare) people together into the dream of an alternative political or economic state. In Walter Benjamin's (1996) terms, binding people together in statefounding violence. The problem is that this binding function once again is based on knowledge of good and evil. Language binds people together with knowledge, with which they can judge and critique the dominant discourse, whilst dreaming of the ideal utopian city. Lacan (see Meylahn 2010:6) also seeks to unbind people from the dominant discourses and specifically also the capitalist discourse, yet he follows a different path - not the path of knowledge and therefore binding people into a good and righteous city, but the path of not knowing and embracing the symptom.

What is needed is an embracing of the digital whilst unbinding it from the capitalist discourse. For example, in Lacan this is done via transference of pure difference from the analyst to the analysant.

In such a context, Christology becomes a public theology not as an ethic or infinite demand nor the dream of a just and righteous city, but as something to be witnessed and testified to in faith.

To understand Christology as public theology in the digital world of the anthropocene, the article will bring Lacan's discourses into conversation with a Christ discourse (see Meylahn 2010). As mentioned above, the idea is to embrace the symptom (see Meylahn 2010:7f.). Humanity is a creature of and in language, where language is the house of being. The digital embraces the linguistic nature of humanity and exploits it by creating the possibility of virtual digital subjects. 
The desire in Lacan's discourse of the analyst is to help individuals to embrace the symptom of a debarred self, rather than seeking to overcome the textual by various discourses (master, university, hysteric; see Meylahn 2010:8). For Lacan's discourse of the analyst the desire was the desire for pure difference, which is then transferred to the analysant. Is the desire for pure difference enough? Or does it not run the danger of itself becoming a conclusive master discourse - so much so that one is again only replacing one master discourse with another master discourse?

Christology following, as argued above, not pure difference but a given-without-givenness or determination-in-the-lastinstance, offers an alternative that can transform the digital whilst embracing the textual - to embrace the symptom and thus the 'reality' of the textual, and by embracing the 'reality' of textual, realising that there are, and always will be, various discourses. It is the sacramental and religious nature of language to bind people into a city, even if it is a Lacanian city of pure difference. It is exactly this religious nature of language that needs to be reckoned with. In the binding (religare) of language on the basis of some or other transcendental decision there are always exclusions. A Christology takes this binding (religious) power of language into consideration by associating with those who are excluded by the dominant grammatisations. Christ's bias for the excluded and marginalised challenges the dominant discourses and crucifies their power and authority. It is this discourse-critical element that is missing in the digital turn. The digital turn embraces the textual and plays in the textual, but is not conscious of the dominant discourses that one unconsciously plays into and is therefore bound to. The focus on what is excluded in the dominant grammatisations loosens the power and authority of the dominant grammatisations, allowing something else to be born: an unbound (non-religious) community where there is neither Greek nor Jew, freeman or slave, man or woman, homosexual or heterosexual, Christian or Moslem, righteous or terrorist, $99 \%$ or $1 \%$ (resurrected community). The attempt is not to overcome pure difference, but to accept that they are given-without-givenness, and to focus on the text and what happens in texts, as argued above. What happens in texts is not the breaking in of the Other. What happens in texts is not the breaking in of some or other text-transcendental truth, but it is the vulnerability of texts themselves - their inability to capture (Begreifen) and communicate conclusively. Texts, as given-without-givenness and determined-in-the-lastinstance on the basis of some or other arbitrary decision, are unifacially turned to the future, as stranger texts.

It is not a matter of welcoming of strangers, but becoming strangers through love for the marginal - those who are excluded from the dominant discourses. In that love for the marginal, it is a matter of witnessing the crucifixion of the dominant discourses and testifying to the opening of what is to what is not: the future. Embracing the textual and in love and faith witnessing the crucifixions of dominant discourses and in hope awaiting the city that is always to come, that will transform all our knowledge into nothing, and thereby continually transforming believers into stranger subjects: aliens in this world.

\section{Conclusion}

Perhaps this is a way of doing theology in the anthropocene. A way that is not caught in the snares of a suicide machine of the sixth great extinction, but offers a way to create lifespaces: by deconstructing the dominant discourses without resorting to anything outside the anthropocene, but focusing on the anthropocene's own contradictions and exclusions.

\section{Acknowledgements Competing interests}

The author declares that he has no financial or personal relationships that may have inappropriately influenced him in writing this article.

\section{References}

Agamben, G., 2010, The sacrament of language: An archaeology of the Oath (Homo Sacer II,3), transl. A. Kotsko, Polity Press, Cambridge.

Barth, K., 2003, God here and now, Routledge, New York.

Benjamin, W., 1996, 'Critique of violence', in M. Bullock \& M.W. Jennings (eds.), Walter Benjamin: Selected writings, vol. 1: 1913-1926, pp. 236-252, Harvard University Press, Cambridge.

Brassier, R., 2001, 'Alien theory: The decline of materialism in the name of matter', PhD thesis, Dept. of Philosophy, University of Warwick.

Brassier, R., 2003, 'Axiomatic heresy: The non-philosophy of François Laruelle', Radical Philosophy 121, 24-35.

Caputo, J.D., 2006, The weakness of God: A theology of the event, Indiana University Press, Indianapolis, Indiana.

Caputo, J.D., 2013, The insistence of God: A theology of perhaps, Indiana University Press, Indianapolis, Indiana.

Crites, S., 1989, 'The narrative quality of experience', in S. Hauerwas \& L.G. Jones (eds.), Why narrative? Readings in narrative theology, pp. 65-88, Eerdmans, Grand Rapids.

Crockett, C. \& Robbins, J.W., 2010. Religion, politics, and the earth: The new materialism, Palgrave and Macmillan, New York.

Crutzen, P., McNeil, J.R. \& Steffen, W., 2007, 'The anthropocene: Are humans now overwhelming the great forces of nature?', Ambio 36(8), 614-621. PMID: 18240674, http://dx.doi.org/10.1579/0044-7447(2007)36[614:TAAHNO]2.0.CO;2

Derrida, J., 1975, 'The purveyor of truth', transl. W. Domingo, J. Hulbert \& M. Ron, Yale French Studies 52, 31-113.

Derrida, J., 1981, Dissemination, transl. B. Johnson, Continuum, New York.

Derrida, J., 1982, Margins of philiosophy, transl. A. Bass, Harvester, Brighton.

Derrida, J., 1995, 'Sauf le nom', in J. Derrida \& T. Duoit (eds.), On the name, pp. 35-88, transl. D. Wood, J.J. Leavey \& I. McLeod, Stanford University Press, Stanford.

Derrida, J., 1997, Of grammatology, transl. G.C. Spivak, John Hopkins Press, Baltimore.

Derrida, J., 2008, 'How to avoid speaking: Denials', in P. Kamuf \& E. Rottenberg (eds.), Psyche: Inventions of the other vol. 2, pp. 143-195, transl. K. Frieden \& E. Rottenberg, Stanford University Press, Stanford.

Ganzevoort, R., 2009, Forks in the road when tracing the sacred: Practical theology as hermeneutics of lived religion, viewed 20 May 2013, from http://www. ruardganzevoort.nl/pdf/2009_Presidential.pdf.

Heidegger, M., 1976, 'Nur noch ein Gott kann uns retten', Der Speigel, 31 May, pp. 193-219, transl. M. Alter \& J.D. Caputo. (Originally in Philosophy Today 20 267-284).

Kearney, R., 2001, The God who may be: A hermeneutics of religion, Indiana University Press, Bloomington.

Kearney, R., 2010, Anatheism: Returning to god after god (Insurrections: Critical studies in religion, politics, and culture), Columbia University Press, New York.

Lacan, J., 1972, 'Seminar on "The Purloined Letter"', transl. J. Mehlman, Yale French Studies 48, 39-72.

Laruelle, F., 1999, 'A summary of non-philosophy', Pli: The Warwick Journal of Philosophy 8, 138-148.

Laruelle, F., 2000, 'Identity and event', Pli: The Warwick Journal of Philosophy, Parallel Processes 9, 174-189. 
Laruelle, F., 2003, 'What can non-philosophy do?', transl. R. Brassier, Angelaki: Journal of the Theoretical Humanities 8(2), 169-189.

Laruelle, F., 2008, 'A science of Christ', paper presented at the Grandeur of Reason: Religion, Tradition and Universalism conference, Rome, 1-4th September.

Laruelle, F., 2010, Philosophies of difference: A critical introduction to non-philosophy transl. R. Gangle, Kindle edn., Continuum, New York.

Laruelle, F., 2011, 'The generic as predicate and constant: Non-philosophy and materialism', in L. Bryant, N. Srnicek \& G. Harman (eds.), The speculative turn: Continental materialism and realism, pp. 237-260, Re-press, Melbourne.

Latour, B., 2005, Reassembling the social: An introduction to actor-network-theory, Oxford University Press, Oxford.

Latour, B., 2010, On the modern cult of the factish Gods, transl. C. Porter \& H. MacLean, Duke University Press, Durham.

Latour, B., 2013, An inquiry into modes of existence: An anthropology of the moderns, transl. C. Porter, Harvard University Press, London.

Levinas, E., 1969, Totality and infinity: An essay on exteriority, transl. A. Lingis, Duquesne University Press, Pittsburgh.

Levinas, E., 1998, Of God who comes to mind, transl. B. Bergo, Stanford University Press, Stanford.

Levinas, E., 2002, 'Diachrony and representation', in J.D. Caputo (ed.), The religious, pp. 76-88, Blackwell Publishers, Oxford.

McLaren, B.D., 2007, Everything must change: Jesus, global crises, and a revolution of hope, Thomas Nelson, Nashville.

Meylahn, J-A., 2010, 'Holistic redemptive pastoral ministry in the fragmented transit hall of existence', HTS Teologiese Studies/Theological Studies 66(1), 1-9. http:// dx.doi.org/10.4102/hts.v66i1.426

Meylahn, J-A., 2013a, 'The hidden potential of pre-theoretical transversal events or advents of a rainbow nation', HTS Teologiese Studies/Theological Studies 69(1), 1-11. http://dx.doi.org/10.4102/hts.v69i1.1305
Meylahn, J-A., 2013b, The limits and possibilities of postmetaphysical God-talk: A conversation between Heidegger, Levinas and Derrida, Peeters, Leuven. (Studies in Philosophical Theology 52.)

Ricoeur, P., 1973, 'The model of the text: Meaningful action considered as a text', New Literary History 5(1), 91-117. http://dx.doi.org/10.2307/468410

Ricoeur, P., 1984, Time and narrative, vol. 1, transl. K. McLaughlin \& D. Pellauer, University of Chicago Press, Chicago.

Scholem, G., 1972, 'Judaica, that name of God and the linguistic theory of the Kabbala', transl. S. Pleasance, Diognes 79, 59-80.

Schrag, C.O., 2002, God as otherwise than being: Toward a semantics of the gift, Northwestern University Press, Evanston, Illinois.

Stiegler, B., 2009, 'The carnival of the new screen: From hegemony to Isonomy, The YouTube Reader', in P. Snickars \& P. Vonderau (eds.), Medienhistoriskt Arkiv 12, 40-59.

Stiegler, B., 2010, 'Technics of decision an interview', Angelaki: Journal of the Theoretical Humanities 8(2), 151-168.

Stoker, W., 2010, 'Culture and transcendence: Shifting religion and spirituality in philosophy, theology, art and politics', paper presented at the Culture and Transcendence conference, Amsterdam, 28-29th October.

Usener, H., 1985, Götternamen: versuch einer Lehre der religiösen Begriffsbildung, Klosterman, Frankfurt am Main

Van den Hoogen, T., 2013, 'Academic table discussion at the University of Pretoria', Spirituality of Foundational theology by Prof. dr. Toine van den Hoogen of the Theology Faculty of Njmegen, Netherlands, 6 June.

Verhaeghe, P., 1995, 'From impossibility to inability: Lacan's theory on the four discourses', The Letter: Lacanian Perspectives on Psychoanalysis 3(Spring), 91-108.

Žižek, S., 2006, Jacques Lacan's four discourses, viewed 2 June 2009, from http:// www.lacan.com/zizfour.htm.

Žižek, S., 2009, 'Dialectical clarity versus the misty conceit of paradox,' in C. Davis (ed.), The monstrosity of Christ: Paradox or dialectic?, pp. 234-306, The MIT Press, Massachusetts. 